\title{
Social Status of the Fish-farmers of Floating-net-cages in Lake Maninjau, Indonesia
}

\author{
Syandri $\mathbf{H}^{1 *}$, Elfiondri ${ }^{2}$, Junaidi ${ }^{1}$ and Azrita $^{3}$
}

${ }^{1}$ Department of Aquaculture, Faculty of Fisheries and Marine Science Bung Hatta University, Padang, Indonesia

${ }^{2}$ Faculty of Humanities, Bung Hatta University Padang, Indonesia

${ }^{3}$ Department of Biology Education, Faculty of Education, Bung Hatta University, Padang, Indonesia

\begin{abstract}
The study surveyed the social status of fish-farming in Lake Maninjau of Indonesia. The stuctured interview using scheduled questionnaires were used in obtaining information from 240 fish farmers randomly selested from eight local sub-districts as the study areas. The eighth sub-districts were divided into three areas which involved the aquaculture zone of the lake. Data obtained were analyzed using descriptive statistics. The findings revealed that majority $(39.16 \%)$ of the fish farmers were male with the age range of $31-40$ years. It was about $55.41 \%$ of the fish farmer having household size $4-6$ person, and $45.83 \%$ educational level was Senior High School graduates. The total annual income from sales of fish were IDR 10000000 -IDR $20000000,37.92 \%$ of fish farmers practiced the integrated fish-farming, and only $52.08 \%$ of the farmers practiced fish-production. $51.25 \%$ of the fish farmers got their information from their friends and fellow farmers. $73.33 \%$ of the fish farmers cultured Tilapia species, $77.91 \%$ of the fish farmers obtained their fingerlings from private hatchery, $96.66 \%$ of fish farmers stated that poor water quality as a major constraints to fish production. The results indicated that floating net-cages activities at the Lake Maninjau played essential role in the lives of fish-farmers for survival.
\end{abstract}

Keywords: Aquaculture; Fish farmers; Lake Maninjau; Indonesia

\section{Introduction}

Food is the most basic necessity for every human being [1-3]. Food is not only necessary to support growth and human development through a series of physiological processes, is also often associated with socio-economic status $[4,5]$. Development of the world community in the 21st century has shown a propensity for changes in behavior and lifestyle and food consumption patterns to fishery products [6$8]$. The sustainability of fish food production is highly dependent on the motivation and participation of fishermen and fish farmers $[9,10]$, technology options are applied and enforced policies and should have a positive impact for their welfare $[4,9,11]$.

Dealing with the social economic status of fish farmer in Lake Maninjau, Syandri examined the study on invesment of floating net cages. He found that the investment was very beneficial economically [12]. He did not examine the social-economic status in perpsective of age, education, marital status, income, household size, and number of floating net cages per household. While in Borgu, Niger State, Ahmed $\mathrm{YB}(2013)$ studied the socio-economic status focused on income of the society and social technology awareness [13]. According to him, the female earned 6000-10.000 $\mathrm{N}$, while male did 11000-30000 with the technology awareness of fish-farming, V-bottom boat, solar-tent driyer and tramel net. Syandri, et al., held reseach on water quality and tropic status in relation to mass fish-death with technology of floating net cages in Lake Maninjau [14]. The bad quality of water had caused fish to die in floating net cages. In addition, Pangemanan et al. studied the feasibility of the floating fich system-fish culture based on environtmental and economic aspects in Lake Tondano, Indonesia, which resulted that all costal areas were feasible for floating fish cage system-fish culture business except area of North Lake Tondano [15]. Study on the cost and return of fish-farming in Saki-East local government area of Oyo State, Nigeria resulted that the fish farming was profitable and expected to continue operating [16], while in Lake Abaya, Ethiopia, Sime SD found that majority of household (62.8\%) gained their icome from agriculture and fishing, where fishing was important source of livehood compared to agriculture [17]. Thus the previous studies did not include the social status of fish-farmers based on the aspects of age, education, marital status, income, household size, and number of floating net cages per household.

The paper examined the aspects in Lake Maninjau. Activity of fish-farming with floating net-cages in Lake Maninjau started in 1992 consisting of 16 units of cages with production of 96 tons [12]. In 2013, the cages increased to be 16,120 units which produced 12,090 tonnes of fish with value production of USD 2.1726 billion [14]. The farmed fish-species are Majalaya (Cyprinus carpio) and Tilapia (Oreochromis niloticus), but recently the Tilapia was more dominant species compared with Majalaya [18]. Fresh water aquaculture in Lake Maninjau was growing so very rapidly that it the society obtained income and jobs in the region $[14,18]$. According to FAO [19], the fishery sector was valuable and its importance was related to employment, livelihood support, poverty reduction, food security as well as foreign exchange. Moreover Singh stated that fisheries sector occupied an important place in the socio-economic development of the country [8].

The objective of the study is to survey the social status of fishfarmers in Lake Maninjau in order to analyze the socio-economic characteristic of the fish farmers, the production level of fish farmers, fish-farming management, and the constraints to the fish farming in the study area.

*Corresponding author: Syandri $\mathrm{H}$, Department of Aquaculture, Faculty of Fisheries and Marine Science Bung Hatta University, Padang, Indonesia, Tel: 9175423212; E-mail: syandri_1960@yahoo.com

Received September 23, 2015; Accepted October 28, 2015; Published January 15,2016

Citation: Syandri H, Elfiondri, Junaidi, Azrita (2015) Social Status of the Fishfarmers of Floating-net-cages in Lake Maninjau, Indonesia. J Aquac Res Development 6: 391. doi:10.4172/2155-9546.1000391

Copyright: $\odot 2015$ Syandri H, et al. This is an open-access article distributed under the terms of the Creative Commons Attribution License, which permits unrestricted use, distribution, and reproduction in any medium, provided the original author and source are credited. 


\section{Methodology}

\section{Area of study}

This study was carried out in Lake Maninjau West Sumatera Province, Indonesia. The lake is a tecto-vulcanic, on geographical position E: $00^{\circ} 12^{\prime} 26.63^{\prime \prime}-$ S: $0^{0} 25^{\prime} 02.80^{\prime \prime}$ and E: $100^{\circ} 07^{\prime} 43.74^{\prime \prime}-\mathrm{E}$ : $100^{\circ} 16^{\prime} 22.48^{\prime \prime}$, located at altitude of $461.50 \mathrm{~m}$ above sea level with the surface area 9,737.50 ha. Based on the Schmidth-Ferguson climate classification, the lake has the characteristics of climate types $\mathrm{A}$ and annual rainfall $3,490 \mathrm{~mm}$. The lake is a natural resource that has a very important role as a tourist destination, Hydroelectric Power Plants with a capacity of $64 \mathrm{MW}$, capture-fisheries and as the farming of floating net-cages [12] . The lake is located in the district of Tanjung Raya divided into 8 local government areas, namely Maninjau, Bayur, Duo Koto, Koto Kaciek, Koto Gadang VI Koto, Koto Malintang, Tanjung Sani, and Sungai Batang (Figure 1).

\section{Sampling technique, sample size and data analysis}

Random sampling techniques were employed in the selection of the samples, in fisheries zones of fisheries development programme of Lake Maninjau. The zones consisted of three zones. Zone I involved Maninjau, Bayur, and Duo Koto. Koto Kaciek, Koto Gadang VI Koto and Koto Malintang were part of zone II. In Zone III, there were Tanjung Sani and Sungai Batang. In the 8 local government areas, 30 fish-farmers were randomly selected as the informats from each of the local governments that totally 240 fish-farmers were randomly selected informants of research. The research used data collected from primary and secondary sources. Primary data were collected by doing the scheduled and structured interview, while secondary sources were collected through library study on textbook and journal publication on Aquaculture. The interview was used to collect data from the fish farmers. The data were analyzed by using descriptive statistics [20].

\section{Result and Discussion}

Socio-economic characteristics of fish farmers floating net-cages as indicated in Table 1, majority of the fish farmers (39.16\%) were $31-40$ years. While the rest, $20.83 \%$ were $20-30$ years, $19.63 \%$ were $41-50$ years, and $19.58 \%$ were above 50 years. The mean age $(60 \%)$ showed that the farmers were relatively young. The young famers were productive and innovative and brave to have investments. Such condition was in line with Silviyunan [21] who examined fish-farmers floating nets cages in Lake Laut Air Tawar. She reported that the age group of 35-44 years (39.36\%) was the most productive farmers. In gender perspective, majority of the respondents $(88.75 \%)$ were males, while $11.25 \%$ were females. The fish-farming was dominated by male in the study area. Generally in Indonesia, majority of fish-farmers in lakes and rivers were men [9] where men played important role in the farming. Unlike in Lake Kanji, Basin Nigeria, the men did not play significant role in the development of the fisheries resources of the lake, but the women played the role [22]. In river state Negeria majority of the fish farmers (34.4\%) were male of the age, 41-50 years old [23]. In addition, marital status of the respondent showed that majority of the fish -famers $(79.16 \%)$ were married, while $16.25 \%$ were single, and $4.58 \%$ were widow. Compared with marital status of cat-fish (Clarias gariepinus) farmers in Ibadan Metropolis, majority of the fish farmers (85.6\%) were married [24].

Most of the respondents' house hold size were 4-6 persons (55.41\%), while $24.58 \%$ of them had $1-3$ persons. The house hold average was 6 persons, it was large family size. It implied that more unproductive people were dependent on the productive ones. In education, most of the respondents (45.83\%) were senior high school graduates, $27.08 \%$ were yunior high school graduates, and $6.66 \%$ were university graduates. The finding was that most of the fishfarmers in the study area were educated people who could easily adopt innovations. This was supported by Pontoh [25], who analized fishery business on floating net cages in the village of Tandengan, Minahasa, North Sulawesi, Indonesia. He found that most of respondents were also Junior High School graduates. Silviyunan also found the same finding on majority of floating-net-cages farmers in Lake Laut Air Tawar, Banda Aceh, Indonesia [21]. Furthermore, in Pujab India education levels of aqua-farmers was university graduate (26\%), senior high school graduates (38\%), and junior high school graduates (22\%) [8]. The main occupation of respondents in the study area was fulltime fish farmers in majority $(71.66 \%)$, and $10.41 \%$ of them were the retired civil servant-farmers. The rest of them worked as businessmen and farmers $(11.25 \%)$ and as civil servants and farmers $(6.67 \%)$. This implied that most of fish farmers devoted their time as fish-farmers.

The farmers had different experience in length. Most of them (37.08\%) had 6-10 year-experience in fish-farming, $25.57 \%$ of them had 11-15 year-experience, and $21.25 \%$ of them had been experinced as the fish farmers for 16-20 years. Thus, most of the fish farmers in the study area were so experienced that they were potential to develop inovation for the increase of production. According to Pontoh $\mathrm{O}$, human resources in the development of aquaculture were very important $[25,26]$. He stated that in the rural areas the human resources played very important role for the implementation of aquaculture operations.

Dealing with the fund of the farming, majority (50.41\%) of the respondents had a personal funding, while $25.41 \%$ of them got funding from juragan, $13.75 \%$ from family, and $9.58 \%$ from Bank allowance. Personal funding could only have 8 units of floating net-cages maximally. Farmers who had funding from juragan and Bank could have more than 8 units of floating net-cages. Majority (61.66\%) of land for farming in the study area belonged to the farmers them selves (their own lands), the rest $24.17 \%$ were rented, and $14.16 \%$ were the cropsharing-rented lands. The annual income of the fish farmers was that majority $(32.08 \%)$ of the farmers earned from IDR $10,000,000$ to IDR $20,000,000,25.42 \%$ earned from IDR $21,000,000$ to $30,000,000$, while $22.5 \%$ earned above IDR 40,000,000. As claimed by Tunde et al. the fish farming was profitbale for the people who worked as the fish farmers. It was a profitably additional job for the people living the study area [16]

The result of the study revealed that majority (52.08\%) of the farmers were fish farmers having business focused on fish-farming activity only, while others were the fish farmers with the integrated fish-farming activities: $20.41 \%$ practiced fish and rice farming, $20 \%$ practiced fish and cocoa farming, and $7.5 \%$ of them practiced fish and cattle farming (Table 2). The integrated fish-farming in a region was highly dependent on the location, topography, rainfall, growingseason, and technology owned by the farmers $[11,27,28]$.

Regarding with the information on the fish farming, majority (51.25\%) of the respondents got the information from their friends and fellow farmers, $29.16 \%$ from mass media, $8.75 \%$ from agents and juragan, while $2.08 \%$ of the farmers got the information from internet (Table 3). Compared with that of River State Nigeria, majority (58.9\%) got information from friends and fellow farmers, and 3.3\% from internet [29]. Table 4 indicated that majority $(73.33 \%)$ of fish farmers cultured Tilapia species as their fingerlings, $17.91 \%$ cultured Common carp, and $8.75 \%$ cultured tilapia and Common carp respectively. Furthermore, majority (77.91\%) of the fish farmers obtained their 


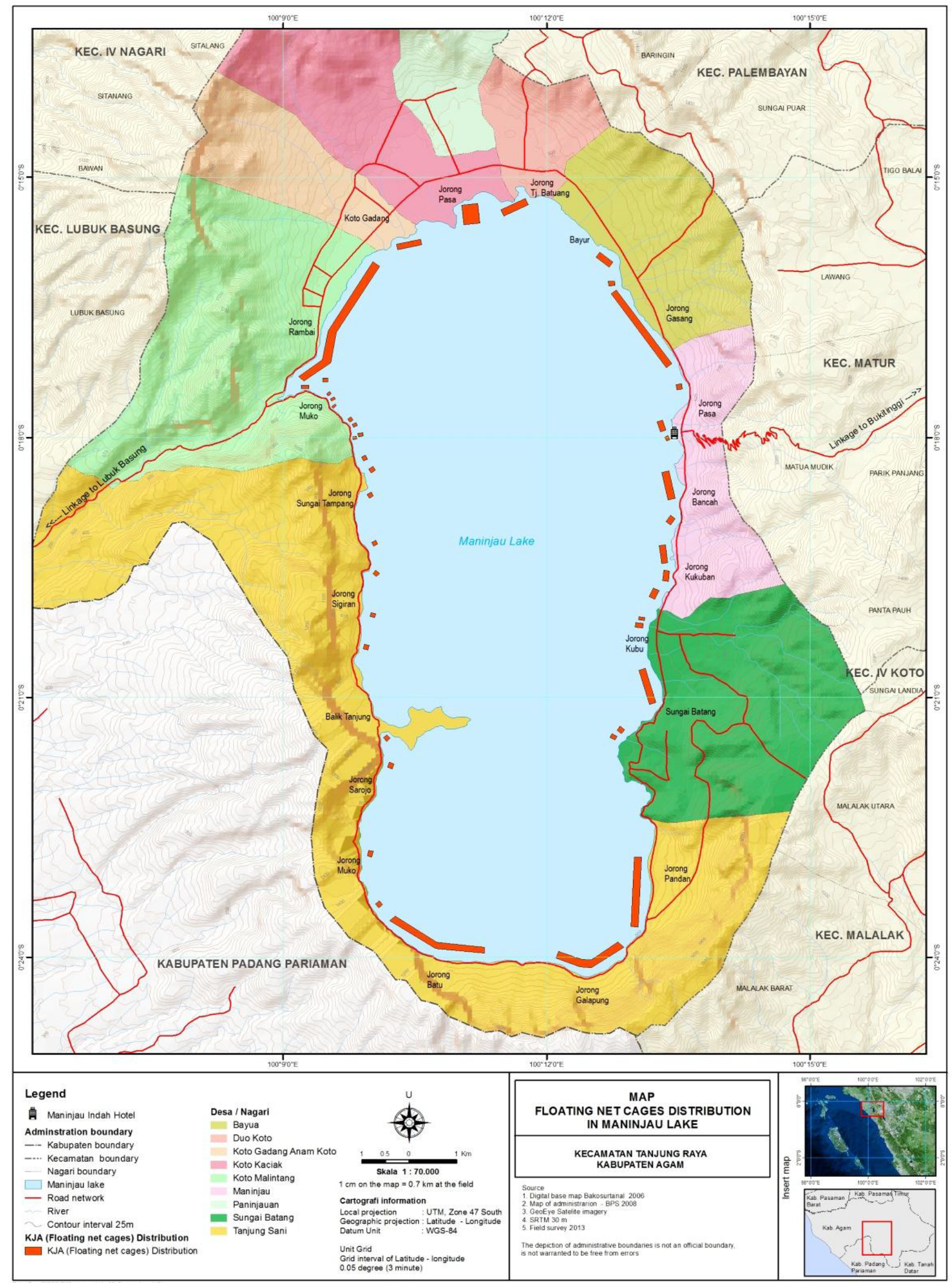

Figure 1: Map of Lake Maninjau of Agam Regency-Indonesia showing the study area. 
Citation: Syandri H, Elfiondri, Junaidi, Azrita (2015) Social Status of the Fish-farmers of Floating-net-cages in Lake Maninjau, Indonesia. J Aquac Res Development 6: 391. doi:10.4172/2155-9546.1000391

Page 4 of 5

\begin{tabular}{|c|c|c|c|}
\hline Parameters & Frequency & Percentase & Mean \\
\hline \multicolumn{4}{|l|}{ Age of respondents } \\
\hline Less than 19 & 0 & 0 & 40,5 \\
\hline $20-30$ & 50 & 20.83 & \\
\hline $31-40$ & 94 & 39.16 & \\
\hline $41-50$ & 49 & 20.41 & \\
\hline More than 50 & 47 & 19.58 & \\
\hline Total & 240 & 100 & \\
\hline \multicolumn{4}{|l|}{ Sex of respondents } \\
\hline Male & 213 & 88.75 & \\
\hline Female & 27 & 11.25 & \\
\hline Total & 240 & 100 & \\
\hline \multicolumn{4}{|l|}{ Marital status of respondents } \\
\hline Single & 39 & 16.25 & \\
\hline Married & 190 & 79.16 & \\
\hline Widowed & 11 & 4.58 & \\
\hline Total & 240 & 100 & \\
\hline \multicolumn{4}{|l|}{ Household size (person) } \\
\hline $1-3$ & 59 & 24.58 & 5 \\
\hline $4-6$ & 133 & 55.41 & \\
\hline $7-10$ & 48 & 20 & \\
\hline Total & 240 & 100 & \\
\hline \multicolumn{4}{|l|}{ Educational level } \\
\hline Primary and below & 49 & 20.41 & \\
\hline Junior High School & 65 & 27.08 & \\
\hline Senior High School & 110 & 45.83 & \\
\hline Graduate and above & 16 & 6.66 & \\
\hline Total & 240 & 100 & \\
\hline \multicolumn{4}{|c|}{ Primary occupation of respondents } \\
\hline Fulltime farming & 172 & 71.66 & \\
\hline Farmings and business & 27 & 11.25 & \\
\hline Farming and civil servant & 16 & 6.67 & \\
\hline Retired civil servant and farmers & 25 & 10.41 & \\
\hline Total & 240 & 100 & \\
\hline \multicolumn{4}{|l|}{ Farming experience (years) } \\
\hline $1-5$ & 23 & 9.58 & \\
\hline $6-10$ & 89 & 37.08 & \\
\hline $11-15$ & 77 & 32.08 & \\
\hline $16-20$ & 51 & 21.25 & \\
\hline Total & 240 & 100 & \\
\hline \multicolumn{4}{|l|}{ Source of venture funding } \\
\hline Personal funding & 121 & 50.41 & \\
\hline Family funding & 33 & 13.75 & \\
\hline Juragan funding & 61 & 25.41 & \\
\hline Bank funding & 23 & 9.58 & \\
\hline Total & 240 & 100 & \\
\hline \multicolumn{4}{|c|}{$\begin{array}{l}\text { Number of floating net cages/ household } \\
\text { (units) }\end{array}$} \\
\hline Less than 4 & 56 & 23.33 & \\
\hline $5-8$ & 71 & 29.58 & \\
\hline $9-20$ & 48 & 20.0 & \\
\hline More than 20 & 65 & 27.08 & \\
\hline Total & 240 & 100 & \\
\hline \multicolumn{4}{|l|}{ Land Ownership } \\
\hline Inherited & 148 & 61.66 & \\
\hline Leased-rent & 58 & 24.17 & \\
\hline Share cropping & 34 & 14.16 & \\
\hline Purchased & 0 & 0 & \\
\hline
\end{tabular}

Total

Annual income from sales of fish

IDR 10000000- IDR 20000000

IDR 21000000 - IDR 30000000

IDR 31000000- IDR 40000000

Above IDR 40000000

Total

Source: Primary survey data, 2015-08.

Table 1: Demographic chararacteristic of fish-farmers $(n=240)$.

Integrated fish farming activities

Fisheries and rice agriculture

Fisheries and cattle farm

Fisheries and cocoa agriculture-plants nutmeg

Fisheries only

Total

Source: Primary survey data, 2015-08.

Table 2: Integrated fish farming activities $(n=240)$.

\begin{tabular}{|l|c|c|}
\hline Sources of information for fish farmers & Frequency & Percentase \\
\hline Extension agents & 21 & 8.75 \\
\hline Friends/fellow farmers & 123 & 51.25 \\
\hline Mass media & 70 & 29.16 \\
\hline Juragan & 21 & 8.75 \\
\hline Literature & 5 & 2.08 \\
\hline Internet & 0 & 0 \\
\hline Total & 240 & 100 \\
\hline
\end{tabular}

Source: Primary survey data, 2015-08.

Table 3: Sources of information for fish farmers $(n=240)$.

\begin{tabular}{|l|c|c|}
\hline Types /species of fingerlings used & frequency & Percentage \\
\hline Tilapia & 176 & 73.33 \\
\hline Common carp & 43 & 17.91 \\
\hline Tilapia and Commoncarp & 21 & 8.75 \\
\hline Total & 240 & 100.00 \\
\hline Source of fingerlings & & \\
\hline Personal hatchery & 48 & 20.00 \\
\hline Government hatchery & 0 & 0.00 \\
\hline Private hatchery & 187 & 77.91 \\
\hline Wild & 5 & 2.08 \\
\hline Total & 240 & 100.00 \\
\hline
\end{tabular}

Source: Primary survey data, 2015-08.

Table 4: Types species and source of fingerlings $(n=240)$.

\begin{tabular}{|c|c|}
\hline Constraints & Percentage \\
\hline Inadequate infrastructure & 68.33 \\
\hline Inadequate supplay of fish feeds & 15.83 \\
\hline Irregular electricity supplay & 17.50 \\
\hline Poor finance & 50.41 \\
\hline Poor hatchery facilities & 20.00 \\
\hline High cost of feeds & 83.33 \\
\hline Hight price of input/production & 88.33 \\
\hline Diseases & 71.66 \\
\hline Poor water quality & 96.66 \\
\hline Poor services & 65.00 \\
\hline High cost of management & 42.50 \\
\hline Poor marketing & 30.41 \\
\hline
\end{tabular}

Source: Primary survey data, 2015-08.

Table 5: Constraints to fish farming in the study area $(n=240)$. 
Citation: Syandri H, Elfiondri, Junaidi, Azrita (2015) Social Status of the Fish-farmers of Floating-net-cages in Lake Maninjau, Indonesia. J Aquac Res Development 6: 391. doi:10.4172/2155-9546.1000391

fingerlings from private hatchery, $20 \%$ of the fish farmers got their fingerlings from personal hatchery. This implies that most of the fish farmers did not have hatchery in their farms.

Table 5 revealed that majority $(96.66 \%)$ of the farmers stated that poor water quality was a major constraint to fish production in the study area. Other factors which were constraints to fish-farming in the study area were: high price of input (88.33\%), high cost of feeds $(83.33 \%)$, diseases $(71.66 \%)$, and inadequate infrastructure $(68.33 \%)$. The constraints factors reduced fish-production and social income in the study area.

\section{Conclusion}

The research resulted in that the aquaculture of the floatingnet cages played an important role to increase fish production and fish farmer's income. Majority of the fish farmers obtained annual income which could support the daily need. In farming, a few farmers practiced the integrated fish-farming, and most of them practiced fishproduction farming. The farmers were dominated by men with the age range of 31-40 years. They had 4-6 person-household in avarage, and educationally majority of them were Senior High School graduates. Information on the farming was gained from their friends and fellow farmers. No information they got from internet due to being busy with their farming. Poor water quality of Lake Maninjau led most of farmers to culture Tilapia species of which the fingerlings derived from privatefarmed hatchery.The poor water quality was a major constraint to fish production.

\section{References}

1. Carolan M (2012) The Food and Human Security Index: Rethinking Food Security and Growth'. Int. Jrnl. of Soc. of Agr and Food 19: 176-200.

2. Kpogue DNS, Grace AA, Ibrahim IT, Guy AM, Emile DF (2013) Influence of dietary protein levels on growth, feed utilization and carcass composition of snakehead,Parachanna obscura (Günther, 1861) fingerlings. International Journal of Fisheries and Aquaculture 5: 71-77

3. FAO (2014) The state of world fisheries and aquaculture, opportunities and challenges.

4. Lakitan B (2010) Research and technology policy for the achievement of food security and improving the welfare of farmers. Seminar Papers of World Food Day XXX, Senggigi, Lombok, 6-8 Oktober 2010.

5. Sari AK, Andrias DR (2013) Socio-economic factors related to household food security of urban fishermen in Surabaya. Media Gizi Indonesia 9: 54-59.

6. Adeyeye El (2009) Amino acid composition of three species of Nigerian fish: Clarias anguillaris, Oreochromis niloticus and Cynoglossus senegalensis. Food Chemistry 113: 43-46

7. Jabeen F, Chaudhry AS (2011) Chemical compositions and fatty acid profiles of three freshwater fish species. Food Chemistry 125: 991-996.

8. Singh DR, Vasisht AK, Kumar S (2015) Profitability and technical efficiency of aquaculture in Punjab, India.Indian J. Fish 62: 49-55.

9. Syandri H, Junaidi, Azrita (2011) Fish Resources Management of bilih fish (Mystacoleucus padangensis Cyprinidae) based local wisdom. Journal of Indonesian fisheries policy 2: 135-143

10. Nazdan, Setiawan B, Sukandar D (2008) Analysis of potential and fisheries management in the perspective of food security in the coastal areas of West Lampung. Journal of Gizi and Food 3: 149-155.

11. Sukadi FM (2002) The improvement of fish culture technology. Journal Iktiolog Indonesia 2: 6I-66.

12. Syandri $\mathrm{H}$ (2003) Cages culture and problems in Lake Maninjau, West Sumatra Province. Journal of Fisheries and Maritime Affairs 8: 74-81.

13. Ahmed YB (2013) Socio-economis status of the fisher folk of yuna adapted village in Borgu local covernment área, Niger State. Journal of Fisheries and Aquatic Science 8: 136-141.
14. Syandri H, Junaidi, Azrita, Yunus $T$ ( 2014) State of aquatic resources Lake Maninjau West Sumatra Province, Indonesia.Journal of Ecology and Environmental Sciences 1: 109-113

15. Pangemanan JF, Harahap N, Soemarno, Polii B (2014) Ecological-economic analysis of floating fish cage-aquaculture business in Tondano Lake, Minahasa Regency, North Sulawesi Province. Scholars Journal of Agriculture and Veterinary Sciences 1: 269-273.

16. Tunde AB, Kuton MP, Olahdipo AA, Olahsunkami LH (2015). Economic analyze of costs and return of fish farming in Saki-East Local Government Area of Oyo State, Nigeria. J Aquac Res Development 2015 6: 2

17. Sime SD (2015). The socioeconomics of small scale fisheries based on Eastern side of Lake Abaya, Ethiopia. International Journal of Fisheries and Aquatic Studies 2: 87-93.

18. Junaidi, Syandri H, Azrita (2014) Loading and distribution of organic materials in Lake Maninjau West Sumatra Province-Indonesia. J Aquac Res Development 5: $1-5$

19. FAO (2008) Fisheries and aquaculture sector overview, Ghana. (December 2010) http://www.fao.org/fishery/countrysector/FICP_GH/en.

20. Steel GD, Torrie JH (1981) Principles and procedures of statistics (2nd edition) McGraw-Hill Book Company. Inc. N. Y. xxi - pp: 633.

21. Silviyanun (2013) Analysis of floating net cage fish farming in LautTawar Lake Aceh Province, Indonesia. Thesis, Department of Geography Education Faculty of Social Sciences, State University of Medan.

22. Nwabeze GO, Ifejika PI, Tafida AA, Ayanda JO, Erie AP, et al. (2013). Gende and fisheries of Lake Kanji, Nigeria : A Review. Journalof Fisheries and Aquatic Science 8: 9-13.

23. Holzlöhner S, Nwosu FM (2014) Fisheries survey in Cross River State, Nigeria Journal of Fishereis and Aquatic Science 9: 221-228.

24. Akinpelu OM, Ayeloja AA, George FOA, Adebisi GL, Jimoh WA, et al. (2013) Gender analysis of processing activities among commercial catfish processors with in Ibadan Metropolis, Oyo State South-Western Nigeria. Journal Aquactic Research Development 4: 1-5

25. Pontoh $O$ (2012) Analysis of fishery business on floating net cages in Tandengan Village Minahasa Regency, North Sulawesi. Pacific Journal 2: 1424-1428.

26. Radheyshyam, Saha GS, Safui L, Eknath AE, Adhikari S, et al. (2013) Status and economy of community fish farming in rural Odisha. Indian Journa Fisheries 60: 59-67.

27. Manurung VT (1997) Status and prospect fish aquaculture with floating net cages in West Java and Central Java. Journal of Research and Development Agriculture 1: 8-15

28. Ayu C, Wuryanto (2010) Model of integrated farming that Is efficient and has impact on sustainable socio economic improvement of farmer households (The case of ground water irrigated dry land farm on Lombok Island). Agroteksos $2: 154-165$

29. Ibemere IF, Ezeano $\mathrm{Cl}$ (2014) Status of fish farming in rivers state, Nigeria Journal of Fisheries and Aquatic Science 9: 321-329. 